\title{
Transvaginal liver resection (NOTES) combined with minilaparoscopy
}

\author{
J. F. Noguera, C. Dolz ${ }^{1}$, A. Cuadrado, J. M. Olea and A. Vilella ${ }^{1}$ \\ Surgery and ${ }^{\prime}$ Gastroenterology Departments. Son Llàtzer Hospital. Palma de Mallorca, Spain
}

\section{RESUMEN}

Objetivo: comunicar la primera resección hepática realizada en humanos mediante cirugía endoscópica transluminal con abordaje transvaginal combinada con minilaparoscopia.

Pacientes y métodos: paciente de 61 años de edad con antecedentes de intervención de Wertheim por carcinoma endometrial a los 50 años y melanoma maligno correctamente tratado a los 59 años, con sospecha por tomografía y resonancia de metástasis hepática en segmento $\mathrm{V}$ próxima a la vesícula biliar. Se indicó cirugía exerética mediante abordaje laparoscópico y se ofreció a la paciente abordaje combinado NOTES transvaginal y minilaparoscópico, que aceptó. La intervención fue realizada por un equipo multidisciplinar compuesto por cirujanos y endoscopistas. Se creó el neumoperitoneo mediante aguja de Veres en el fondo umbilical y posteriormente se insertaron dos trócares en el abdomen, transumbilical de $5 \mathrm{~mm}$ y en hipocondrio derecho de $3 \mathrm{~mm}$. Se hallaron numerosas adherencias pélvicas que obligaron a colocar un trócar accesorio en el cuadrante inferior izquierdo de 5 $\mathrm{mm}$, empleado exclusivamente para la adhesiolisis. Se liberó e identificó el fondo de saco vaginal y se realizó la entrada vaginal con trócar de $12 \mathrm{~mm}$ que permitió el paso del endoscopio hasta el espacio subhepático.

Resultados: la resección hepática (hepatectomía limitada en segmento V) y colecistectomía se realizaron usando una combinación de instrumentos endoscópicos y laparoscópicos. La resección en bloque fue extraída por vía transvaginal mediante tracción endoscópica. No existieron complicaciones postoperatorias y la paciente fue dada de alta a las 48 horas del procedimiento.

Conclusiones: la resección hepática transvaginal es posible y segura cuando la realiza un equipo multidisciplinario con experiencia en estos campos. La cirugía endoscópica transluminal a través de orificios naturales (NOTES) es una técnica emergente que permite realizar el procedimiento con menor invasión en la pared abdominal, mejor tolerancia por el paciente y con un beneficio estético. Será, además, una vía de importantes avances para la medicina y la innovaciones tecnológicas.

Palabras clave: Resección hepática. Colecistectomía transvaginal. NOTES. Minilaparoscopia.

Received: 28-03-08.

Accepted: 01-04-08.

Correspondence: José F. Noguera Aguilar. Servicio de Cirugía. Hospital Son Llàtzer. Crta. de Manacor, km 4.07198 Palma de Mallorca, Illes Balears, Spain. e-mail: jnoguera@hsll.es

\begin{abstract}
Objective: to report on the first liver resection performed on a human being by a transvaginal NOTES approach combined with minilaparoscopy.

Patients and methods: a sixty-one-year-old woman with a history of Wertheim's hysterectomy for endometrial carcinoma 10 years ago, and malignant melanoma correctly treated in 2006, had suspected segment- $\mathrm{V}$ liver metastasis near the gallbladder by CTscan and MRI. The indication for a laparoscopic approach was made, and a combined transvaginal and minilaparoscopic resection was offered and accepted by the patient. The procedure was performed by a multidisciplinary team composed of surgeons and gastroenterologists. It involved creating a pneumoperitoneum by placing a Veres needle in the umbilical fundus, followed by the insertion of a 5-mm trocar. A second, 3-mm trocar was placed in the right upper quadrant. A lot of pelvic adhesions were found in the major pelvis, and it was necessary to place a third, 5-mm trocar in the left abdominal side. It was employed only for the adhesions, not for liver resection. Adhesions were removed to reveal the minor pelvis and the vaginal fornix. A colpotomy was performed with a 12-mm trocar placed inside the vagina, which allowed the insertion of the videogastroscope as far as the liver hilum.

Results: liver resection (segment-V partial resection) and cholecystectomy were performed by using a combination of working tools inserted through the entry port for the minilaparoscopy and the videogastroscope. The en bloc resection was removed transvaginally through the videogastroscope. There were no postoperative complications, and the patient was discharged after 48 hours.

Conclusions: transvaginal liver resection is possible and safe when performed by a multidisciplinary team. Natural orifice transluminal endoscopic surgery (NOTES) is an emerging modality that seeks to be less invasive, better tolerated, and more respectful of esthetics. It will probably open the way for very important medical and technological innovations.
\end{abstract}

Key words: Liver resection. Transvaginal cholecystectomy. NOTES. Minilaparoscopy.

Noguera JF, Dolz C, Cuadrado A, Olea JM, Vilella A. Transvaginal liver resection (NOTES) combined with minilaparoscopy. Rev Esp Enferm Dig 2008; 100: 411-415. 


\section{INTRODUCTION}

Natural orifice translumenal endoscopic surgery (NOTES) comprises several new endoscopic and surgical entryways into the abdominal cavity, with potential advantages over conventional laparoscopic surgery, including its being less invasive and even less traumatic to the abdominal wall. NOTES in animals was first described by Kalloo in 2004 (1). In early 2007, Zorron (Brazil) reported the first transvaginal cholecystectomy (2). In March 2007, Bessler reported a laparoscopically-assisted transvaginal cholecystectomy (3). In April 2007 the procedure was performed by Marescaux using only an abdominal trocar that allowed him to create pneumoperitoneum and to exert traction on the gallbladder with forceps (4). Branco reported their first transvaginal cholecystectomy with hybrid approach using a $5 \mathrm{~mm}$ trocar in the umbilicus for retracting the gallbladder and control the pneumoperitoneum (5). In December 2007 an important communication is reported by Zorron (6), with four patients who have undergone transvaginal NOTES cholecystectomy. The first NOTES transvaginal cholecystectomy was performed in Spain by Dr. J. Noguera's team at Son Llàtzer Hospital in Palma de Mallorca in October 2007 (7).

Currently, a second line of medical technology research concerns "minilaparoscopy," or laparoscopy with instruments of smaller diameter and with the least possible number of entry ports in the abdominal wall. Reducing the size of laparoscopy instruments has provided us with $2.8 \mathrm{~mm}$ optics and working channels measuring $3 \mathrm{~mm}$ in diameter. By thus reducing invasiveness and surgical trauma, one can expectedly attain better postoperative results, particularly in terms of postoperative pain, complications of the abdominal wall from incisions, recovery time, as well as a lesser impact on aesthetics.

A vaginal access route to the abdominal cavity, its opening, and its sutured closure are standardized procedures; the risk of infection and of short- and long-term local complications is very small (8-10). The short distance that separate the posterior surface of the vagina from the vaginal introitus eliminate the serious disadvantages of the transgastric, transcolonic, and transvesical access routes.

\section{PATIENTS AND METHODS}

Sixty-one-year-old female with a history of Wertheim's hysterectomy by endometrial carcinoma 10 years ago and malignant melanoma correctly treated in 2006 (radical excision and centinel node biopsy without limphatic metastasis). During the follow-up is detected in the liver a quistic $20 \mathrm{~mm}$ tumour, suspicious of segment $\mathrm{V}$ liver metastasis from malignant melanoma near the gallblader by CT-scan and MRI (Fig. 1). Indication of liver radical resection by laparoscopic approach was made

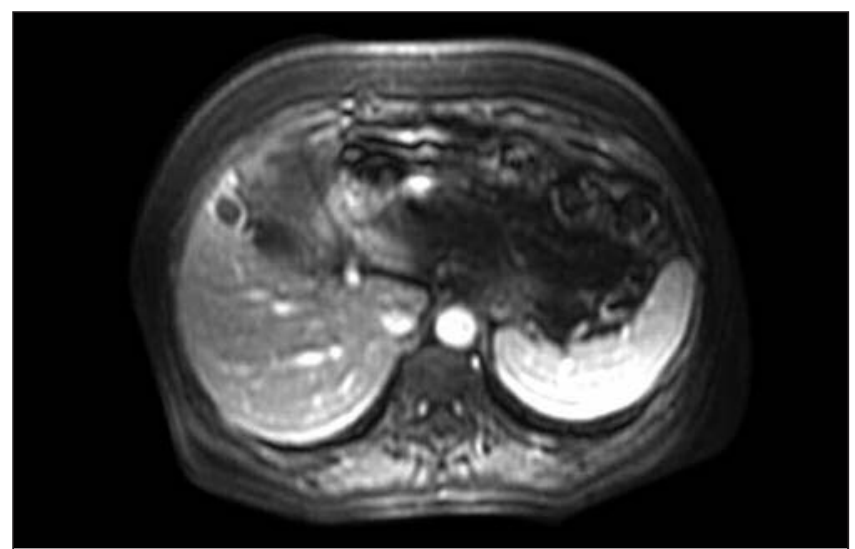

Fig. 1. MRI with a quistic tumour near the gallblader, in segment V. Radiological characteristics orientate towards malignance.

and a combined transvaginal and minilaparoscopic resection was offered and accepted by patient. Liver function tests were normal, and the patient was scheduled for surgery after informed consent for a transvaginal resection was obtained. We contacted the Ethics and Clinical Research Committee of the Autonomous Community of the Balearic Islands and obtained specific informed consent. We used a $180 \mathrm{H}$ videogastroscope (Olympus, Hamburg, Germany) that was sterilized with ethylene oxide, along with the irrigation bottle and its connecting tube. The surgery was performed on $17^{\text {th }}$ December 2007. Operative field: The vagina, perineal region, and abdominal wall were disinfected with povidone-iodine, and urine was removed with a urinary catheter. General anesthesia with orotracheal intubation was applied, and prophylactic antibiotic therapy with amoxicillin plus $2 \mathrm{~g}$ clavulanic acid was given intravenously, according to protocol. The patient was placed in modified Lloyd-Davies position, with her right leg lower and maneuvered back and forth from the Trendelenbourg to the anti-Trendelenbourg position in order to displace the bowels and get the best view possible of the operative field.

Pneumoperitoneum was created by placing a Veress needle in the umbilical fundus. Subsequently, a working $5 \mathrm{~mm}$ trocar was inserted in the same spot. A second, 3 $\mathrm{mm}$ trocar was placed in the right upper quadrant and a third $3 \mathrm{~mm}$ trocar was necessary to remove a lot of pelvic adhesions due to previous ginecologic surgery. This trocar was not employed for liver resection.

After liberation of adhesions, with umbilical visual monitoring (Karl Storz full HD Platform Image ${ }^{\mathrm{TM}}$ ), a rigid vaginal trocar measuring $12 \mathrm{~mm}$ in diameter and $15 \mathrm{~cm}$ in length (Tyco International Ltd., Norwalk, Connecticut, USA) was inserted into the peritoneal cavity trought the bottom of the vagina. A plastic bag (Unimax 5" $\times 7$ ", Unimax Medical Systems Inc., Taipei, Taiwan) was introduced through this trocar for the purpose of retrieving the liver and gallbladder after removal. 
A single channel videogastroscope was introduced through the vaginal trocar as far as the abdominal cavity. First the bag for retrieving the gallbladder was placed in the subphrenic space. We then proceeded to identify the liver tumour near the gallbladder and to attain the best position possible from which to begin dissecting the cystic pedicle and to perform cholecystectomy and liver resection.

We began to dissect the hilum of the gallbladder, the omental and peritoneal adhesions, and the cystic duct and artery, which were sealed with clips and sectioned afterwards. The cholecystectomy was performed from the hilum to the fundus with electrocoagulation. En bloc resection was made with a wide partial resection of segment $\mathrm{V}$ including the tumour seen in radiological explorations. Liver parenchymal transection was performed using harmonic scalpel (Ethicon Endo-Surgery, USA) (Fig. 2) and radiofrequency tissular sealing (Tissuelink Medical, Dover, USA). The liver resection bed was inspected to ensure there was no hemorrhage or leakage of bile (Fig. 3). During this entire surgical time the videogastroscope kept shifting its position and angle in order to get a view that would make it possible to make lliver transection, dissect, clip, and remove the liver and gallblader. Liver resection was made with laparoscopic

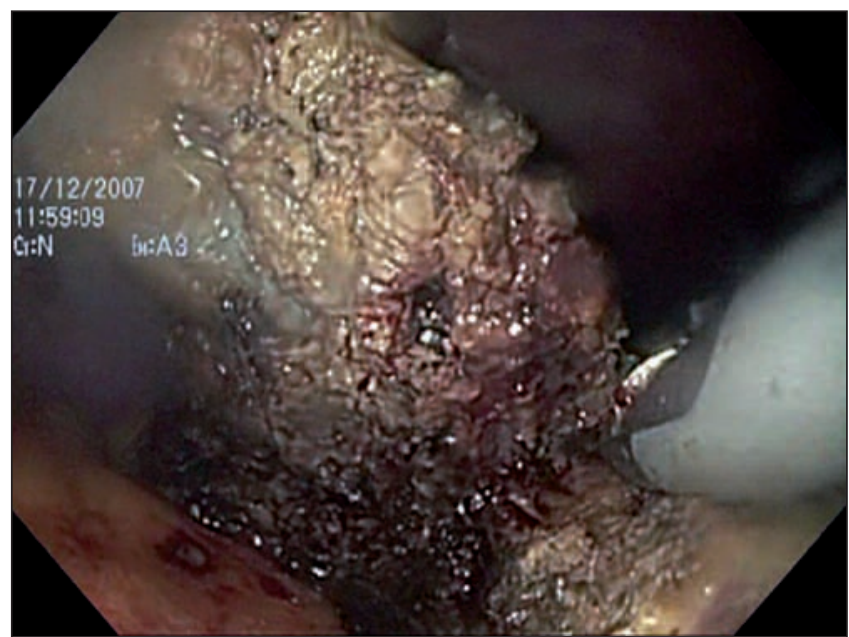

Fig. 2. Liver parenchimal transection with harmonic scalpel. Endoscopic view.

instruments (Karl Storz, Tuttlingen, Germany) with help of endoscopic ones.

With a "mouse-toothed" forceps (Medi Globe GmbH, Achenmüle, Germany) that was slipped through the working channel of the videogastroscope (Fig. 4), the plastic bag containing the en bloc resection was gripped and slowly retracted until it had entered the vaginal trocar about $4-5 \mathrm{~cm}$. Under laparoscopic visual monitoring, the videogastroscope, the forceps holding the bag and the vaginal trocar were removed en bloc, until the bag be-

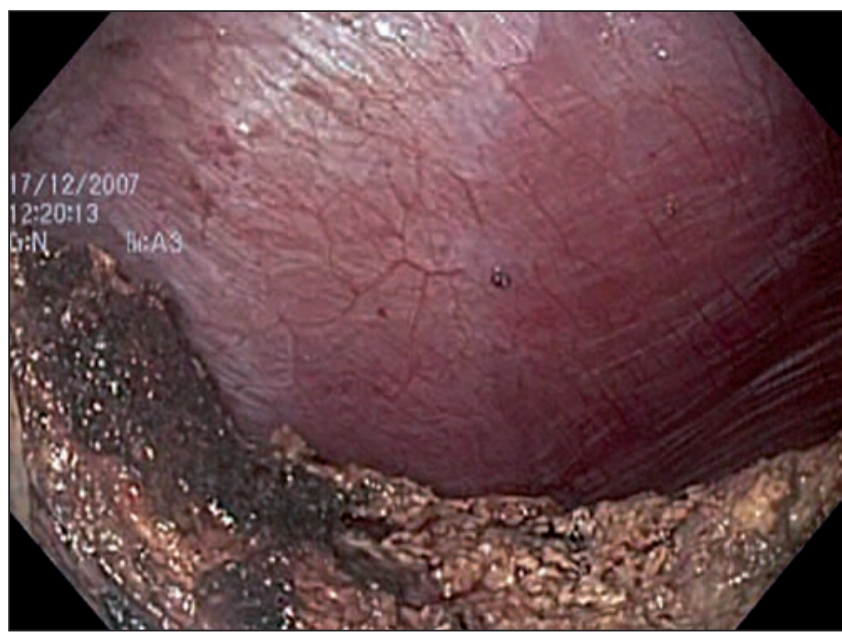

Fig. 3. Endoscopic view of bed of liver resection.

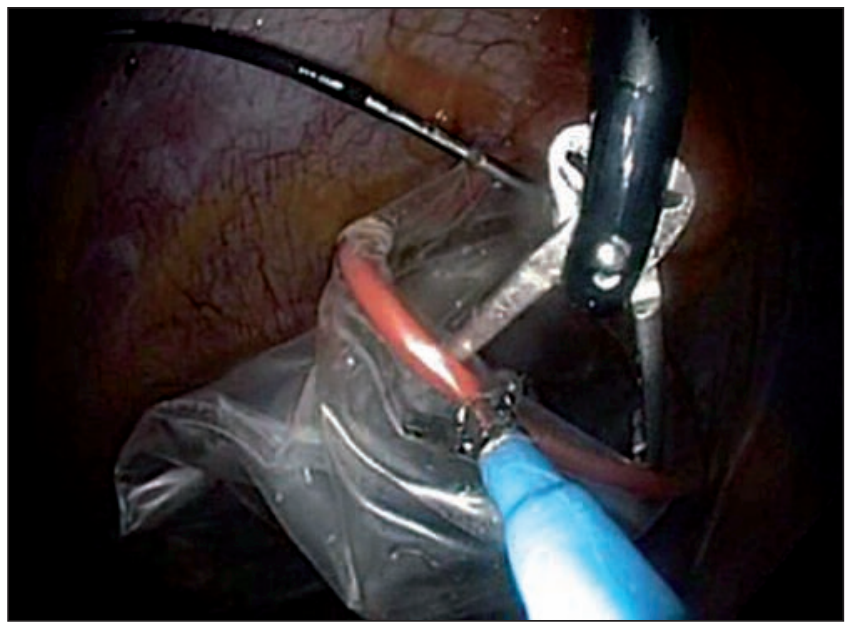

Fig. 4. Endoscopic instrument, "mouse-toothed" forceps, taking the edge of extraction bag.

came clearly visible inside the vagina and, with the help of a pair of Köcher forceps, is completely removed and closed the vaginal incision with two absorbable sutures. The operation lasted 110 minutes in all. There were no postoperative complications, and the patient was discharged in 48 hours. Histological examination showed a liver non-typical adenoma, without malignant cells.

\section{DISCUSSION}

The laparoscopy has joined of clear form in the field of the general surgery and has represented one of the innovations with major repercussion of last years. The most common indication for laparoscopic liver resection is a 
solitary liver metastasis from a colorectal cancer, but it may also be used for hepatocellular carcinoma, non-colorectal metastasis and for benign liver tumours or cysts. Open surgical resection is performed through a large incision across the abdomen. In laparoscopic liver resection, the abdomen is insufflated with carbon dioxide and a number of small incisions are made to provide access for the laparoscope and surgical instruments. The resected liver is enclosed in a bag and removed, through an incision in the umbilical area or a transverse laparotomy. In hand-assisted laparoscopic, the surgeon introduces one hand in the abdomen while maintaining the pneumoperitoneum required for laparoscopy.

In our working group laparoscopic liver resections are made for selected patients since 2006 and our programme for transvaginal cholecystectomy started in October 2007. When the committee of liver tumours of our hospital decided to remove the patient's tumour, we offered the patient the possibility of perform a transvaginal en bloc resection of the gallbladder and a partial hepatectomy in segment $\mathrm{V}$ by a hybrid approach, fusion of endoscopic translumenal surgery and laparoscopy.

In NOTES closure of the natural orifices through which the abdominal cavity is accessed is one of the critical features. There are no validated methods that are safe and effective for closing orifices in the stomach or intestines, despite the fact that different systems have been described, such as one with anchor sutures (11-13), the Eagle Claw $(14,15)$, a system combining forceps with a suturing needle (16), an endoscopic stapler (17), and a system using multiple clips (18). These systems have different drawbacks, they are clumsy, and they must undergo further improvement before they can be passed through an endoscopic working channel and used to suture securely, simply, and rapidly. Conversely, the vagina provides easy, safe access, and colpotomy is a procedure that gynecologists have been performing routinely for years. The rich network of elastic fibers in the vaginal wall accounts for its elasticity and allows for the great temporal distension that is needed during labor.

The transvaginal route has also been described occasionally for removing non-gynecological organs, such as nephrectomy or hemicolectomy specimens (19-22). Posterior colpotomy is practically painless and complications from colpotomy are very rare.

Pneumoperitoneum has to be created in any type of NOTES. The introduction of a Veress needle, normally in the umbilical fundus, works well functionally and aesthetically. The incision can be used to place a trocar with a small diameter and slide in laparoscopic instruments. In our case, we used three trocars because of pelvic adherences derived of a previous Wertheim procedure that needs a wide removal; this trocar was not used for en bloc resection. The last entry port was the working channel of the videoendoscope, which allows passage of different auxiliary systems, in addition to being useful as a light source and camera.
The videoendoscope was introduced via the colpotomy after directly inserting into the peritoneal cavity a rigid trocar measuring $12 \mathrm{~mm}$ in diameter and $15 \mathrm{~cm}$ in length. The trocar made it possible to aim the videoendoscope toward the subhepatic space and stabilize it. We feel it is a good idea to introduce the bag for retrieving the surgical specimen when the videoendoscope is inserted, since it prevents having to withdraw it once and introduce it again. Accessing the liver's operative field may be difficult for endoscopists, who are not used to moving about and finding their way inside the peritoneal cavity.

The procedure for liver and gallbladder resection need not differ from a classical laparoscopic approach. To operate through this entry port and with these instruments, the surgeon must meet certain conditions: he must be highly experienced in performing liver and biliary laparoscopic surgery, be adept at applying this technique with few working channels, be familiar with minilaparoscopy tools and, finally, have become accustomed, through previous practice with a simulator or experimental animals, to the view provided by the videoendoscope. Additionally, the videoendoscope is much more sensitive to slight changes in traction or in the position of the working tools, making it necessary to change the field and the angle of vision often. It is essential that the endoscopist and the surgeon go through a period of training together so they become used to each other and learn to coordinate and synchronize their gestures and manoeuvres.

The traction exerted on the gallbladder with forceps through the endoscopic working channel was not effective. We feel forceps should be designed specifically for endoscopy so as to be able to exert traction and hold things in place with longer, rotating blades having an atraumatic surface. A conventional two-channel videoendoscope would have made collaboration easier, but its effectiveness is limited by the inability to make spatial movements or to angle the two working channels independently of each other. On the other hand, the videoendoscope's role as a camera may not be compatible with the tasks performed by endoscopic instruments through working channels, given their mutual structural dependence. It was the surgeon who made the liver and gallbladder en bloc resection while endoscopic instruments helped in traction and dissection. We believe this hybrid procedure is the best approach as long as endoscopic materials and technologies adapted for surgery through videoendoscopes are not available. This is supported by the fact that it took us 110 minutes to complete our first transvaginal liver resection.

In spite of the experience of the group in dissection with endoscopic instruments in NOTES cholecystectomy, the inability to have harmonic energy and radio-frequency across the channels of work, they force to fulfil the hepatic transection with laparoscopic instruments of $5 \mathrm{~mm}$. As Shih thinks (23), the hybrid approach could be used for decrease the invasiveness of laparoscopic surgery and for removal the specimen by a natural orifice. 


\section{REFERENCES}

1. Kalloo AN, Singh VK, Jagannath SB, et al. Flexible transgastric peritoneoscopy: A novel approach to diagnostic and therapeutic interventions in the peritoneal cavity. Gastrointest Endosc 2004; 60: 114-7.

2. Zorron R, Filgueiras M, Maggioni LC, Pombo L, López Carvalho G, Lacerda Oliveira A. NOTES transvaginal cholecystectomy: Report of the first case. Surgical Innovation 2007; 14 (4): 279-83.

3. Bessler M, Stevens PD, Milone L, Parikh M, Fowler D. Transvaginal laparoscopically assisted endoscopic cholecystectomy: A hybrid approach to natural orifice surgery. Gastrointest Endosc 2007; 22: (in press).

4. Marescaux J, Dallemagne B, Perretta S, Wattiez A, Mutter D, Coumaros D. Surgery without scars: Report of transluminal cholecystectomy in a human being. Arch Surg 2007; 142: 823-6.

5. Branco Filho AJ, Noda RW, Kondo W, Kawahara N, Rangel M, Branco AW. Initial experience with hybrid transvaginal cholecystectomy. Gastrointest Endosc 2007; 66 (6): 1245-8.

6. Zorron R, Maggioni LC, Pombo L, Oliveira AL, Carvalho GL, Filgueiras M. NOTES transvaginal cholecystectomy: Preliminary clinical application. Surg Endosc 2007; Nov 20 (Published online).

7. Dolz C, Noguera JF, Martín A, et al. Colecistectomía transvaginal (NOTES) combinada con minilaparoscopia. Rev Esp Enferm Dig 2007; 99 (12): 698-702.

8. Ghezzi F, Raio L, Mueller MD, Gyr T, Butarelli M, Franchi M. Vaginal extraction of pelvic masses following operative laparoscopy. Surg Endosc 2002; 16: 1691-6.

9. Horng SG, Huang KG, Lo TS, Soong YK. Bladder injury after LAVH: A prospective, randomized comparison of vaginal and laparoscopic approaches to colpotomy during LAVH. J Am Assoc Gynecol Laparosc 2004; 11: 42-6.

10. Teng FY, Muzsnai D, Pérez R, Mazdisnian F, Ross A, Sayre JW. A comparative study of laparoscopy and colpotomy for the removal of ovarian dermoid cysts. Obstet Gynecol 1996; 87: 1009-13.

11. Fritscher-Ravens A, Mosse CA, et al. Transluminal endosurgery: Single lumen access anastomotic device for flexible endoscopy. Gas- trointest Endosc 2003; 58: 585-91.

12. Ikeda K, Fritscher-Ravens A, Mosse CA, et al. Endoscopic full-thickness resection with sutured closure in a porcine model. Gastrointest Endosc 2005; 62: 122-9.

13. Ikeda K, Mosse CA, Park PO, et al. Endoscopic full-thickness resection: Circumferential cutting method. Gastrointest Endosc 2006; 64: 82-9.

14. Hu B, Chung SC, Sun LC, Kawashima K, et al. Eagle Claw II: A novel endosuture device that uses a curved needle for major arterial bleeding: A bench study. Gastrointest Endosc 2005; 61: 266-70.

15. Hu B, Chung SC, Sun LC, et al. Endoscopic suturing without extracorporeal knots: A laboratory study. Gastrointest Endosc 2005; 62: 230-3.

16. Fritscher-Ravens A. Transgastric endoscopy -a new fashion, a new excitement. Endoscopy 2007; 39: 161-7.

17. Kaehler G, Grobholz R, Langner C, et al. A new technique of endoscopic full-thickness resection using a flexible stapler. Endoscopy 2006; 38: 86-9.

18. Raju GS, Shibukawa G, Ahmed I, et al. Endoluminal suturing may overcome the limitations of clip closure of a gaping wide colon perforation. Gastrointestinal Endoscopy 2007; 65: 906-11.

19. Rovio PH, Heinonen PK. Transvaginal myomectomy with screw traction by colpotomy. Arch Gynecol Obstet 2006; 273: 211-5.

20. Gill IS, Cherullo EE, Meraney AM, Borsuk F, Murphy DP, Falcone $\mathrm{T}$. Vaginal extraction of the intact specimen following laparoscopic radical nephrectomy. J Urol 2002; 167: 238-41.

21. Wilson JI, Dogiparthi KK, Hebblethwaite N, Clarke MD. Laparoscopic right hemicolectomy with posterior colpotomy for transvaginal specimen retrieval. Colorectal Dis 2007; 9: 662.

22. Branco AW, Filho AJ, Kondo W, Noda RW, Kawahara N, Camargo AA, et al. Hybrid transvaginal nephrectomy. Eur Urol 2007; Nov 5 (Published online).

23. Shih SP, Kantsevoy SV, Kalloo AN, Magno P, Giday SA, Ko CW, et al. Hybrid minimally invasive surgery -a bridge between laparoscopic and translumenal surgery. Surg Endosc 2007; 21 (8): 1450-3. 